\title{
A Road to Grace: Homi Bhabhan Reading of Disgrace
}

\author{
Min Wang \\ College of Foreign Languages, Chongqing Jiaotong University, Chongqing, 400074, China \\ Xiaoyan Tang \\ College of Foreign Languages, Chongqing Jiaotong University, Chongqing, 400074, China
}

\begin{abstract}
This study centers around two kinds of people in J. M. Coetzee's novel Disgrace: the whites and the blacks. The white protagonist David Lurie, with his strong colonialist ideology, projects his dominance over the women characters and his racial superiority over the blacks. But now to his disgrace, he is mimicked by the blacks, either in the way of rape or by means of the use of the English language and farming skills. But what Coetzee mainly wants to show is not that the whites are being revenged for their past deeds and they could do nothing but wait for punishment. Actually, he is pointing out the way out of disgrace for the whites.
\end{abstract}

Index Terms-J. M. Coetzee, Disgrace, Homi Bhabha, mimicry, hybridity, grace

\section{INTRODUCTION}

In The Location of Culture, Homi Bhabbha quotes a passage from a missionary in India who wrote in some considerable rage:

Still everyone would gladly receive a Bible, and why? That he may store it up as a curiosity; sell it for a few price; or use it for waste paper.... Some have been bartered in the markets.... If these remarks are at all warranted then an indiscriminate distribution of the scriptures, to everyone who may say he wants a Bible, can be little less than a waste of time, a waste of money and a waste of expectations. For while the public are hearing of so many Bibles distributed, they expect to hear soon of a correspondent number of conversions (Bhabha, 1994, p.95).

In this passage, the white missionary attempts to convert the native Indians into Christianity by requiring them to mimic their way of reading and adoring Bible. But such attempts would surely fail in that although the natives receive Bible from the whites willingly, how it would be used could only depend on the natives themselves. Here we could see that they are using it for their own purpose, not to read them piously, but to barter them in the market or use them as waste paper, to the anger of the missionary. Here we see the failure of the colonizers' strategy of mimicry.

For Bhabha, mimicry is a strategy of colonial power/knowledge for an approved, revised Other to facilitate colonial domination, as Thomas Macaulay's infamous 1835 "Minute on Indian Education" writes: "We must at present do our best to form a class who may be interpreters between us and the millions whom we govern; a class of persons, Indian in blood and color, but English in taste, in opinions, in morals, in intellect" (Childs, 1997, p.130). Mimicry relies on resemblance, on the colonized becoming like the colonizer but always remaining different. Yet, the very fact of the authority's near duplication produces a powerful representation of counter-domination. "To be Anglicized is emphatically not to be English" (Bhabha, 1994, p.95). Thus, mimicry repeats colonial authority as a presence that is 'partial', both incomplete and virtual, which finally disturbs the power and difference on which that authority is based.

\section{Mimicry in Disgrace}

In the passage above quoted from The Location of Culture, the Indians are mimicking the whites' eager reception of the Bible, only for their own purpose even in the colonial times. But in Disgrace, J. M. Coetzee's first novel about the post-apartheid South Africa, mimicry, which was actively utilized by the whites in the colonial times as a mean of governing, brings disaster to them in the new South Africa. Those, which used to be the symbols of victory and ruling for the whites have been attached new meanings by the blacks. For instance, when the white protagonist David Lurie goes to the black man Petrus's party with his daughter Lucy, he describes the decoration on a black man and his actions in the following words:

[A]round his neck, a gold chain form which hangs a medal the size of a fist.....Symbols struck by the boxful in a foundry in Coventry or Birmingham; stamped on the one side with the head of sour Victoria, regina et imperatrix, on the other with gnus or ibises rampant; medals, Chieftains, for the use of. Shipped all over the old Empire: to Nagpur, Fiji, the Gold Coast, Kaffraria.

The man is speaking, orating in rounded periods that rise and fall. He (Lurie) has no idea what the man is saying, but every now and then there is a pause and a murmur of agreement from his audience, among whom, young and old, a mood of quiet satisfaction seems to reign (Coetzee, 1999, p.135).

The passage sets up a tension between the antiquated symbolic language of empire and that of the black man's oration, delivered in the house of a kinsman who has just become a landowner in a region that was once called British. 
The design on the medal, Victoria's visage backed by the decorative emblems of exotic lands, lays bare its now defunct purpose - to define and domesticate otherness. The speaker's words are clearly set in contrast to those on the nineteenth-century shipping labels: "Medals, Chieftains, for the use of." The phraseology of the label is a figure for all defunct definitions, and it rhymes with the words we encounter earlier in the novel: "William Wordsworth (1770-1850), nature-poet," and "David Lurie (1945-?), commentator upon, and disgraced disciple of, William Wordsworth" (Coetzee, 1999, p.46). This echo is not accidental. The evocative incident with the black orator seems to invite comparison with an earlier scene in which Lurie was lecturing to a resistant audience at Cape Technical University about the Mont Blanc section of The Prelude. Though he tries, rather awkwardly, to transfer the Romantic sublime to an African landscape the students' incomprehension suggests that it is only Lurie, author of Wordsworth and the Burden of the Past, who still needs to apprehend the African landscape in this fashion (Barnard, 2003, p.215-216).

Western language and Western poetry have lost its function to domesticate the natives - they are, rather, on the very verge of disgrace, for the medal with Victoria's visage has become just a decoration for the natives instead of subjugation, and Western literature has become a mere burden for the African students. If we say whites here have only met silent objection for the natives do not take any action to oppose the whites actively, the independence of the mimic men in the new South Africa are exerting new pressure on and even bringing disgrace to them now.

\section{INDEPENDENCE OF THE MimiC MAN PETRUS}

As has been quoted above, Thomas Macaulay told the Indian rulers in 1835, "We must at present do our best to form a class who may be interpreters between us and the millions whom we govern; a class of persons, Indian in blood and color, but English in taste, in opinions, in morals, in intellect." Here in South Africa, the former white rulers had tried to form a class of interpreters, African in blood and color, English in taste, in opinions, in morals and in intellect. But their task was only partially realized. In Disgrace, we find a man who is a sort of interpreter for the whites in the past, African in blood and color, but essentially African in taste, in opinions, in morals, and in intellect. That man is Petrus.

Petrus could be regarded as a qualified interpreter in the past. He has been an "apt scholar". He learned English and farming skills from the whites and worked hard for them on their farms. He is, in Lucy's words, a black with "his head screwed on right" (Coetzee, 1999, p.64). So when Lurie comes to Lucy's farm and gets to know Petrus for the first time, he concludes that "Petrus seems a good man" (Coetzee, 1999, p.64), for he is much satisfied with Petrus' words of self-inferiority: "I am the gardener and the dog-man" (Coetzee, 1999, p.64). The colonizer must have felt happy with him, which is suggested by what Coetzee quotes from Robinson Crusoe in his Nobel Lecture:

I was greatly delighted with him [Friday], and made it my business to teach him everything that was proper to make him useful, handy, and helpful; but especially to make him speak, and understand me when I spoke; and he was the aptest scholar there ever was (Coetzee, 2003).

But Petrus is no longer the obedient mimic one, no longer an interpreter for the whites, he has gained his own independence now. "[G]ardener and the dog-man" as he is now, this new black farmer is eager to shed these humble roles. He has tried and succeeded in the course of the novel in building himself a new house that "cast[s] a long shadow" (Coetzee, 1999, p.197), and he schemes to ensure that his line will not only survive but dominate. It is surely not accidental that this man should bear the name "Petrus," the same name as the humble foreman in Nadine Gordimer's story "Six Feet of the Country," in which a group of black farm worker is denied the right to give a proper burial to a family member. Ambitious, resourceful, and, above all, aware that the political tables have turned, "this new Petrus," as Lurie at one point calls him (Coetzee, 1999, p.151), is readily grasped as the post-apartheid counterpart to Gordimer's character, ready to claim his six feet of the country-and more. He is now actively using what he has mimicked from the whites including English language and farming skills for his own purposes.

In 1817, a correspondent of the Church Missionary Society wrote to London describing the method of English education in India: "These (English) sentences might be so arranged as to teach them whatever sentiments the instructor should choose" (Bhabha, 1997, p.106). The colonizers wishfully thought that the natives were such stupid idiots that they would follow them at any time and at any place, while the fact is that the sentiments they learned from the English language is not what the instructors chose for them, the natives are forming their own individual sentiments now, as what Petrus does in Disgrace, to the disappointment and embarrassment of the old master David Lurie.

In the novel, Lurie mentions the English language many times. One reason is that he was a professor of Modern languages for most of his university career, so he is quite sensitive to that; the second reason is that the language has been mimicked by the blacks for their own purposes and new meanings have been attached to it. So once he says that, "Stretches of English code whole sentences long have thickened, lost their articulations, their articulateness, their articulatedness. Like a dinosaur expiring and settling in the mud, the language has stiffened" (Coetzee, 1999, p.117). Lurie keenly feels this in his conversation with Petrus.

Petrus tells Lurie that Lucy is forward-looking, "She is a forward-looking lady, not backward-looking" (Coetzee, 1999, p.136), for she allows his new pipe to cross her land. Petrus's mastery of the English language reminds Lurie that he himself is becoming his own master, not like the times in the past when he was still a servant to his white master. It reminds us, too that "not only imperial medals but the resources of the imperial language were brought to 'Kaffraria' for 'the use of' the region's inhabitants" (Barnard, 2003, p.217). The conversation between the former master and slave is changed into another kind, no longer the old style of question and answer, utterance and echo. 
Petrus's mimicry of the English language makes Lurie angry, and his mimicry of farming skills lets Lurie feel resented, too, to the disgrace of the whites. He is very deft at fitting pipes when Lurie tells him that he knows nothing about regulators. But Petrus needs his help not in terms of advice on pipefitting or plumbing but to hold things, to pass him tools, to be his handyman. The positions between the former master and slave have changed. Like the later scene when Lurie watches Petrus ploughing the land with a tractor swiftly, and thinks they are "all very unlike Africa" (Coetzee, 1999, p.151), we find that the mimic man has overtaken the master. He has gained his independence and equality with him. So it is no wonder that for a man with deep-rooted colonial ideology, such a scene is of great significance: "He would not wish to be marooned with Petrus on a desert isle" (Coetzee, 1999, p.137), because this Friday does not want to continue to follow his master's instructions now.

This also resonates with Coetzee's Nobel lecture in which there lives a new Friday like Petrus. Here Friday is dashing across the kingdom of Britain and sending reports of different places to Robin. Robin is surprised by the writing ability of Friday. He is writing as well as - and even better than - his master. He loves the parrot more than Friday, but the parrot speaks no word taught by his master; on the contrary, Friday could do that. He could even work out sentences that his master has never thought of before:

For he wields an able pen, this man of his, no doubt that. Like charging Death himself on his pale horse. His own skill, learned in the counting house, was in making tallies and accounts, not in turning phrases. Death himself on his pale horse: those are words he would not think of. only when he yields himself up to this man of his do such words come (Coetzee, 2003).

Friday does better than his master Robin, so does Petrus than Lurie. Their mimicry of their masters has become an active tool for their own purposes.

\section{METAPHORICAL INVERSION OF RAPE}

In 1994, the first ever democratic elections were held in South Africa. In May 1994 Nelson Mandela was inaugurated as the country's president at the head of a strongly ANC government. From that time on, the new leaders in the government have been devoted to righting wrongs and establishing new social and racial relations. Yet, the hatred toward the whites accumulated in the colonial times still remains despite the establishment of democratic government, as young Pollux in Disgrace shouts at Lurie and her daughter, "We will kill you all!" (Coetzee, 1999, p.207). As the blacks' extensive poverty out of long history of colonization by the whites does not end with the white disempowerment, to pour their angry feelings towards the whites, they begin to make use of those colonial strategies back to their old masters. So, in Coetzee's novel Disgrace, we find the blacks' mimicry of the Westerners does not stop at merely the English language and farming skills, they are mimicking whites' rape, too.

The European colonization of Africa has been termed the "rape" of Africa. As Ronald Hyam has written: "Sex is at the very heart of racism...Sexual fears are obviously capable of manipulation for political ends, such as the maintenance of white control" (Hyam, 1992, p.203-204). Coetzee in his novel Disgrace just makes use of such a metaphor on his protagonist David Lurie. His description of Lurie's sexual affairs in the novel and the disgrace brought about gives us the impression that the disgrace of the protagonist's sexuality is a metaphor of the downfall of colonialism which is typically reflected in his sexual affairs with three women in the novel.

Lurie grew up in a family of women. Women's company made him "a lover of woman and, to an extent, a womanizer" (Coetzee, 1999, p.7), and he enjoyed their admiration in his youth. But as he is growing old, such powers ended suddenly one day. Glances slid over and passed through him. He has to learn to "pursue" them or even to "buy" them if he wants.

One object is the prostitute Soraya. He likes her because her temperament is "rather quiet, quiet and docile" (Coetzee, 1999, p.21), and a "ready learner, compliant, pliant (Coetzee, 1999, p.207), even though their intercourse is "rather dry, even at its hottest." When Soraya leaves him for he found out her double life, she changes her object to the new secretary in his department. But their sexual affair does not please him because she is too active: "Bucking and clawing, she works herself into a froth of excitement that in the end only repels him (Coetzee, 1999, p.9). After that one encounter, Lurie avoids abruptly, leaving her feel puzzled, hurt and angry. In fact, what Lurie wants is not mutual intercourse at all, as Charles Sarvan points out: "Lurie does not desire mutuality but domination, hence his relationships with women who are much younger - and passive" (Sarvan, 2004, p.27).

Such relationships find its best expression in his seduction of his student Melanie. Melanie is beautiful, young, and most important of all, she is compliant. He takes her to his house for supper, asks her to watches a film with him, and seduces her a few days later, though she has resisted mildly. He is quite satisfied for he enjoys not only young beauty but also the sense of domination. Despite his own observation that this seduction of Melanie is "not rape, not quite like that" (Coetzee, 1999, p.25), the action he does to Melanie suggests something strongly like that. He arrives at Melanie's flat and "thrusts himself upon her" (Coetzee, 1999, p.24), and in which she neither resists nor participates in the sex that follows this invasion. Indeed, Luries observes that "she had decided to go slack, die within herself for the duration" (Coetzee, 1999, p.25). Subsequently, he describes himself "kneeling over her, peeling off her clothes, while her arms flop like the arms f a dead person" (Coetzee, 1999, p.89). He also imagines her, after the violation," running a bath, stepping into the water, eyes closed like a sleepwalker's" (Coetzee, 1999, p.25). So from the terms of the description we could only conclude that Lurie's invasion of Melanie is rape indeed, as Michael Marais has suggested that "the scene 
must be read as Lurie's attempt to possess the Other, to assert control over her" (Marais, 2000, p.175).

Sex as a metaphor of colonialism is not unusual in Coetzee's novels. He often makes use of the motifs, such as torture, rape, and murder to represent metaphorically what whites have done to non-whites. For instance, in "The Narratives of Jacobus Coetzee," the gun to the colonizer Jacobus Coetzee is a major symbol. Killing means to him he is not alone, and death proves there is life. When Jacobus returns to the Namaquas and the servants who abandoned him for their freedom, he sentences them to death in the name of God. He and the soldiers with him torture, rape and totally destroy the Namaqua and the four former servants (Post, 1986, p. 67-77). So in Disgrace, by relating Lurie's imposing of sexuality on women, Coetzee is making use of this motif again to symbolize whites' rape of Africa in the past centuries. Only here, winning belongs to the other party.

To express their pensive feelings toward the whites, the blacks have to resort to other means when they find unsatisfactory solution from the government, which strongly calls for forgiveness rather than for natural justice publicly. Mimicry of the whites' crimes toward them is just part of the scheme. In explaining Breytenbach's idea on rural violence, Coetzee says:

Farm murders, and crimes in general against whites - even the crime directed against the Breytenbachs when their home in Montagu is broken into and vandalized--are indeed part of a larger historical plot which has everything to do with the arrogation of the land by whites n colonial times (Coetzee, 2001, p.256).

In Disgrace, the blacks are mimicking Lurie's rape of Melanie by raping his daughter Lucy. The text constructs a clear parallel between Lurie's rape of Melanie and the gang rape of his daughter, Lucy, on her smallholding in the Eastern Cape town of Salem. As in the earlier scene, Lucy is "surprised "by "intruders" who " thrust" themselves "upon her" (Coetzee, 1999, p.24). Moreover, death also forms a motif in the later scene. After the rape, Lucy describes herself as follows: "I am a dead person and I do not know yet what will bring back to life" (Coetzee, 1999, p.161). Like Melanie, she tries to cleanse herself of the violation (Coetzee, 1999, p.97-98). Most importantly, there is a clear link between Lurie's loss of Melanei after his failure to possess her and his estrangement from his daughter following her rape by the three intruders.

It is evident that Coetzee has chosen masculine and feminine sexualities as the main metaphor for the disempowerment of white South Africans. Coetzee describes two kinds of people in his novel Disgrace: the whites and the blacks. The white protagonist David Lurie, with his strong colonialist ideology, projects his dominance over the women characters and his racial superiority over the blacks. But now to his disgrace, he is mimicked by the blacks, either in the way of rape or by means of the English language and farming skills. But what Coetzee mainly wants to show is not that the whites are being revenged for their past deeds and they could do nothing but wait for punishment. Actually, he is pointing out the way out of disgrace for the whites.

\section{HYBRIDITY FOR GRACE}

By borrowing the idea of hybridity from Jacques Derrida, Bhabha indicates that the exercise of colonial authority is always bringing discourses into connection with other texts and discourses, the effect of which is a hybridization that destabilizes simple meanings, in other words, to facilitate colonial domination, the colonizers must change their own way of speaking and reacting. The purpose is to hybridize the colonial culture and the colonized, which in the end is bound to shift the colonial power and to question its discursive authority. This suggests that colonial discourse is never wholly in the hands of the colonizers.

Bhabha takes the English Bible and its dissemination in India as an example. The Word of God is complicated by the natives' responses that "how can the word of God come from the flesh-eating mouths of the English?" and "how can it be the European book, when we believe it is God's gift to us?"(Bhabha, 1994, p.135) The translation of the Bible into the Indian languages creates a hybridized Word of God. So Bhabha says hybridity is a partial and double force because it is a return of the content and form of colonial authority that "terrorizes authority with the ruse of recognition, its mimicry, its mockery" (Bhabha, 1994, p.115).

Thus, the nature of the colonial authority is questioned and displaced. In Disgrace, Petus's intentional use of the English language is a sufficient proof, as has been discussed above. Lurie feels the difference between his own use of the English language and Peturs's at any encounter, but he could not tell what is wrong with it, because it is his colonial forefathers who disseminated the English language in South Africa for their rule and dominance, and therefore inevitably created a hybridized English language, which questions the authority of the so-called pure English language.

What Bhahha illustrates in The Location of Culture is under the condition that colonial authority is in power, and hybridity is just a means for them to facilitate their control. So, the resistance produced toward colonial discourse and authority is internal, not external. But the changed power relations in South Africa have changed whites' active involvement in hybridity, too, as the former colonizer and the colonized are now standing on what is believed an equal footing. Here the former colonizers are not employing it for means of dominance but existence and grace, which is illustrated in the white characters' different ways of hybridity in Disgrace.

\section{DAVID LuRIE's Cultural Hybridity}

As the name implies, cultural hybridity is to understand, respect cultural differences on an equal basis, not like what 
Bhabha has described in The Location of Culture. In Disgrace, it means that in order to continue to stay on the land of South Africa, and in order to retrieve the sense of grace after so many disgraceful events, Lurie must give up his idea of Western superiority to hybridize white culture and black culture, more specifically, to come to sympathize with and to accept the blacks and to hybridize Western literature and black native culture.

The following is excerpted from Coetzee's Jerusalem Prize acceptance speech of 1987:

At the heart of the unfreedom of the hereditary masters of South Africa is a failure of love. To be blunt: their love is not enough today and has not been enough since they arrived on the continent; furthermore, their talk, their excessive talk, about how they love South Africa has consistently been directed toward the land, that is, toward what is least likely to respond to love: mountains and deserts, birds and animals and flowers (Coetzee, 1992, p.97).

What is clearly implied in his speech is that what the whites want in South Africa is merely the occupation of its land and the exploitation of its natural resources. Their love does not extend as far as toward the blacks. The natives to them are nothing but the obstacle to their occupation of the land, thus the frequent happening of rape, murder and killing. In Disgrace, the protagonist David Lurie has walked along the same road as his forefathers psychically. But he is also different from them for the ending is not the same. He becomes a changed person due to his encounter with the animals especially the dogs, and the happenings on her daughter on her farm.

Lucy's rape by three blacks gives Lurie a hard lesson on love and friendship, but dogs play an even bigger role in changing Lurie's "fixed temperament". For all his stubbornness, Lurie finds himself undergoing changes, particularly regarding the value of animals' lives, despite his best efforts to resist them.

He has an early argument with Lucy, an animal enthusiast, about animals' ontological status, in which he subscribes to the conventional wisdom: "As for animals, by all means let us be kind to them. But let us not lose perspective. We are of a different order of creation from the animals" (Coetzee, 1999, p.74). This topic resurfaces later, when Lurie reluctantly decides to help a local woman named Bev Shaw at her animal clinic in Grahamstown. "They can smell what you are thinking" (Coetzee, 1999, p.81), she tells him on the first day; he remains unconvinced. Still, Lurie finds himself responding to the animals he helps treat in unnervingly animal-like ways. When at one point he is helping Bev calm an ailing dog that must be put down, Lurie realizes that "he gives off the wrong smell (They can smell your thoughts), the smell of shame" (Coetzee, 1999, p.142). Becoming bewildered, "He does not understand what is happening to him. Until now he has been more or less indifferent to animals" (Coetzee, 1999, p143). At this moment, however, "he does not seem to have the gift of hardness" (Coetzee, 1999, p.143).

Lurie's gradual change is evident here. But the most significant change of his fixed temperament and fixed ideas come when he resigns his teaching post in the university and comes to stay on her daughter Lucy's farm.

At first, even after the rape of his daughter by the three blacks on the farm, Luries claims that he is too old to change and repeats this claim on a number of occasions. The point, though, is that he does change in the course of the novel. On Lucy's suggestion, he decides to engage in charity work, which he, facetiously, describes as making "preparation for past misdeeds" (Coetzee, 1999, p.77). Lucy's farm manager Petrus acquires two sheep to provide meat for a party and ties them to a stake, which Luire considers "a miserable way to spend the last two days of one's life" (Coetzee, 1999, p.125). He finds that a "bond seems to have come into existence between himself and the two," that suddenly and without reason, their lot has become important to him" (Coetzee, 1999, p.126). Other animal deaths at the hands of humans take place as well, and Lurie is much more intimately involved with these. One is the shooting of the dogs that are boarding in Lucy's kennel during an attack on the farm by the three blacks, who beat and burn Lurie, rape Lucy, and loot the farmhouse. Lurie digs a grave for these dogs and "trundles the corpses over in a wheel barrow" (Coetzee, 1999, p.110).

The most striking form of animal death is the one in which Lurie plays a direct role, aiding Bev Shaw at a local animal clinic where dogs and other ailing or unwanted animals are put down. Lurie's "whole being is gripped by what happens in the theatre," and what grips him is the spectacle of a creature facing its last moment and, once again, the prospect of the animal's foreknowledge: "He is convinced the dogs know their time has come!" (Coetzee, 1999, p.43). Watching Bev comfort a goat that she is about to inject, he says, "Perhaps he has already been through it. Born with foreknowledge, so to speak... They know how death comes to a goat. They are born prepared," an opinion that draws a skeptical response from Bev: "I don't think we are ready to die, any of us, not without being escorted"((Coetzee, 1999, p. 83-84). Escorting these creatures, both to the table where they are dispatched and to the incinerator where they are disposed of, is the role that Lurie takes on himself. The epithet "dog-man," applied by Mrs. Curren to Verceuil in Age of Iron, returns in Disgrace, attached first to Petrus, who cared for the dogs in Lucy's Kennel, and then, with much resonance, to Lurie, who conducts the dogs in Bev's clinic to their deaths: "A dog-man: a dog undertaker; a dog psychopomp: a harijan" (Coetzee, 1999, p.146).

Thus, in spite of Lurie's resolution not to change, it is the dogs that unleash his emotions - "the more killings he assists in, the more jittery he gets" (Coetzee, 1999, p.142). He cries and "does not understand what is happening to him" as his indifference towards animals dissipates from an "abstract" disapproval of cruelty to a personal commitment to the dogs and, through them, to "his idea of the world" (Coetzee, 1999, p.146). In "offering himself to the service of dead dogs," the "selfish" Lurie finds a kind of grace for himself and the dogs, a way of working through the endlessness of his skepticism and towards repentance, a state that Lurie earlier described to the tribunal as belonging to "another world, to another universe of discourse" (Coetzee, 1999, p. 58). In the process, Lurie comes to understand the meaning of 
charity, care and love: "He has learned by now, from [Bew Shaw], to concentrate all his attention on the animal they are killing, giving it what he no longer has difficulty in calling by its proper name: love"(Coetzee, 1999, p. 219).

As the colonizers often took the animals and blacks as being in the same inferior positions, therefore, from what we witness in Lurie's change toward animals from despise to sympathy in Disgrace, we may easily conclude his change of attitudes toward blacks, too. Also, though Coetzee does not give us clear evidence of Lurie's change of stereotypical views of blacks, his change of attitude toward Western literature tell us this. Learning of love from the sufferings of animals and his daughter changes his attitude toward Western literature and lets him realize where grace lies. "Art is not salvation, but art can point to where salvation may lie" (Tremaine , 2003, p.594-595).

Lurie's attitude toward Wordsworth experiences three stages. The beginning of the novel sees Lurie offering a course named the Romantic Poets to his students. He admires Wordsworth very much. He tells Melanie that "Wordsworth has been one of my masters" and "the harmonies of The Prelude have echoed within him" (Coetzee, 1999, p.13). But the situation changes gradually later, when he reads the story reported in the Herald about the attack on Lucy's farm, he is rather glad to have been not mentioned the connection between Ms Lurie's father and David Lurie, "disciple of nature poet William Wordsworth" (Coetzee, 1999, p.116), because he thinks these "dead" masters "have not guided him well"(179). The final turn of change comes near the end of the story. He finally realizes that Wordsworth is not to blame, but his way of reading Wordsworth is wrong. What he has drawn from these masters' poetry is nothing but the excuse to pursue pretty girls.

At the same time, we find Lurie's changing attitude toward African rural life, too. When he goes to visit Lucy's farm, what impresses him is just the "sparse, bleached grass" and the "[p]oor land, poor soil" (Coetzee, 1999, p.64), but after a series of disgraceful events happening on him, with his daughter working diligently on the land, he discovers its beauty now. There is "the gentle sum, the stillness of mid-afternoon, bees busy in a field of flowers" (Coetzee, 1999, p.218). He plans to care for Lucy's child of mixed blood and begins to shift his attention to the beautiful rural life in Africa from Western literature now: "The truth is, he has never had much of an eye for rural life, despite all his reading in Wordsworth. Not much of an eye for anything, except pretty girls; and where has that got him? Is it too late to educate the eye?" (Coetzee, 1999, p.218).

What best signifies Lurie's cultural hybridity is his playing of the musical instrument banjo, which is of African origin, to mourn Byron's lover, Teresa. At first, he wants to write a chamber opera Byron in Italy to express his meditation on love between the sexes. He means to write about Byron's love affair with Teresa in Italy where the people were "[1] ess hemmed in by convention, more passionate" (Coetzee, 1999, p.15). First he plans to borrow the Western lush orchestration like Strauss, and later he tells Lucy he inclines toward "a very meager accompaniment—violin, cello, oboe or maybe bassoon" (Coetzee, 1999, p.63). But such an idea does not materialize for he has gradually lost his belief in the Western tradition. Byron in real life did not live a good life as he has expected and the Western musical instruments gave him no inspiration at all, thus the "unmoving state of the Byron project" (Coetzee, 1999, p.141) until he finds Lucy's toy “the odd little seven-stringed banjo" (Coetzee, 1999, p.184).

When the sound of the piano hinders him in writing the music for Byron it Italy, Lurie recovers a banjo form Lucy's old books and toys. But the "silly plink-plonk of the toy banjo" teaches him a lot. Months ago, he thought that his place in the opera should be between Teresa's and Byron's: "between a yearning to prolong the summer of the passionate body and a reluctant call from the long sleep of oblivion" (Coetzee, 1999, p.184), so as to write about their love and passion. Now he finds that his place is neither to act as Teresa or as Byron, but "in the music itself, in the flat, tinny slap of the banjo strings" (Coetzee, 1999, p.184). The little banjo begins to lead Lurie to cultural hybridity and to point to him where the salvation lies. From then on, he no longer follows Byron, but Teresa, who lived a rather wretched life after Byon went to Greece, and mourns for her, and he hears another voice, too, which he has never heard before. The voice belongs to Byron's daughter, Allegra. She was unlovely, unloved and neglected by her famous father, and was passed form hand to hand and finally given to the nuns to look after, dying. Banjo helps Lurie to recover his conscience, to find another side of life that is occupied by the suffering and wretched. That is what Africa has taught him, and that also points out where his latter part of life should go.

Richard A. Barney suggests that Lurie may also be finding an oblique way to navigate past his estrangement from his daughter; remarkably, however, he remains nearly oblivious to the relevance this has for the crucial problem of racial relations in the story (Barney, 2004, p.21). It is true that, in several places, Coetzee links animal with racial contempt in Lurie's perceptions - just before the three black males attack him and Lucy, we read that the youngest one, a boy named Pollux, has "piggish eyes." Later, Lurie will make this bestial slur explicit when he calls Pollux a "jackal boy" and a "swine". But we should also note Lurie's change of attitude toward animals during the progression of the novel. He has come to sympathize with and love them.

Besides, Lurie's acceptance of Lucy's child of mixed blood out of rape by the three blacks is another evidence of his changed opinion toward racial relations. In the past, the distance between the white and the native found expression in the fear of miscegenation, because the colonizers thought it violated the boundary between races, creating half-caste children with no natural home. The novels of Sarah Gertrude Millin, an English-speaking South African active between the 1920s and the 1950s, are full of the preoccupation with mixed blood. Miscegenation tainted a family indelibly; future generations might deny it successfully for brief periods, but the taint would always come back to give them away (Mallaby, 1992, p.74-75). Such stereotypical racial discrimination is found in Lurie's words and actions at first, but the 
novel finally witnesses his cultural hybridiy.

\section{CONCLUSION}

What Coetzee means to portray is never only the protagonist himself or just to tell the distinct story of the few white characters. He attempts to describe the destined disgrace of those white South Africans who still obstinately cling to colonial ideology and who are ready to display it in whatever form. However, Coetzee's literary power does not stop here. He is really warning the whites of the danger of stubborn colonial ideology and is pointing a road out of disgrace for them.

Colonialism nowadays has by no means disappeared, and still is a real phenomenon. It is with the world as vision or powerful ideology. We may find the number of articles in British and American newspapers and magazines in recent years calling for recolonization of Africa. This is actually the evidence of whites' racial superiority, and they are trying to find means of justification of continuing imperialist activity. By portraying the disgrace of a typical white South African, Coetzee foretells the doomed disgrace of colonial ideology and actions, and suggests that the only way out is to give them up, and to reach compromise with the natives so that grace can be gained, as what Lurie obtains at the end of the novel Disgrace.

\section{REFERENCES}

[1] Barnard, Rita (2003). "J. M. Coetzee's Disgrace and the South Africa Pastoral." Contemporary Literature 14. $2: 199-224$.

[2] Barney, Richard A (2004). "Between Swift and Kafka: Animals and the Politics of Coetzee's Elusive Fiction." World Literature Today January-April: 17-23.

[3] Bhabha, Homi k (1994). The Location of Culture. London: Routledge.

[4] Childs, Peter and R. J. Patrick Williams. (1997). An Introduction to Post-Colonial Theory. London: Prentice Hall.

[5] Coetzee, J. M. (1999). Disgrace. London: Secker and Warburg.

[6] Coetzee, J. M. (1992). Doubling the Point: Essays and Interviews. Ed. David Attwell. Cambridge: Harvard University Press.

[7] Coetzee, J. M. (2003). He and His Man. http://www.nobelprize.org/nobel_prizes/literature/laureates/2003/coetzee-lecture-e.html.(accessed 29/3/2005).

[8] Coetzee, J. M. (2001). Stranger Shores. New York: Penguin Books.

[9] Hyam, Ronald (1992). Empire and Sexuality: The British Experience. Manchester: Manchester University.

[10] Sarvan, Charles (2004). "Disgrace: A Path to Grace?” World Literature Today January-April: 26-9.

[11] Mallaby, Sebastian (1992). After Apartheid: The future of South Africa. New York: Random House.

[12] Marais, Michael (2000). "'Little Enough, Less than Little: Nothing': Ethics, Engagement, and Change in the Fiction of J. M. Coetzee." Modern Fiction Studies 46.1: 159-82.

[13] Post, Robert M. (1986). "Oppression in the Fiction of J. M. Coetzee." Critique 32.2: 67-77.

[14] Tremaine, Louis (2003). "The Embodied Soul: Animal Being in the Work of J. M. Coetzee." Contemporary Literature 44. 4: 587-611.

Min Wang was born in Chongqing, China in 1978. She received her M.A. degree in literature from Sichuan International Studies University, China in 2005.

She is currently a lecturer in the College of Foreign Languages, Chongqing Jiaotong University, Chongqing, China. Her research interests include English literature, ESP Teaching and translation.

Xiaoyan Tang was born in Sichuan, China in 1967. She received her M.A degree in literature from Southwest University, China in 2001.

She is currently a lecturer in the College of Foreign Languages, Chongqing Jiaotong University, Chongqing, China. Her research interests include English literature, ESP Teaching and business English translation. 